\title{
THE VALUE OF THE \\ NARRATIVE TEACHING \\ OBSERVATION TO DOCUMENT \\ TEACHING BEHAVIORS
}

Niki Young, Western Oregon University

A central mission of teaching and learning centers is to help faculty members improve their teaching. The teaching observation is an established tool to support this effort. Although educational developers have created general guides and forms for conducting teaching observations, the literature contains few examples of observation narratives. This chapter offers detailed examples of these narratives, deconstructing the process and demonstrating the value of narrative to document teaching behaviors. This chapter extends and develops the literature, showing how-and making explicit why-we do what we do, in the interest of making our work transparent and replicable.

I am a teacher at heart, and there are moments in the classroom when I can hardly hold the joy. When my students and I discover uncharted territory to explore, when the pathway out of a thicket opens up before us, when our experience is illuminated by the lightning-life of the mind-then teaching is the finest work I know.

-Parker Palmer

Dear Fellow Teachers, What do you do when silence breaks out in your class, the times when you suddenly forget everything you were going to say, or you ask a question no one answers, and you sit there wishing you were dead, blush rising from the throat, face hot, throat clenched?

-Jane Tompkins 
No monuments record the bravery of teachers.

-Jane Tompkins

College teaching can, at times, be joyful and exhilarating, or painful and frustrating. One of the most important responsibilities of faculty developers, and a central mission of teaching and learning centers, is to "help faculty members develop, assess, and refine their teaching skills" (Frantz, Beebe, Horvath, Canales, \& Swee, 2005, p. 73). Classroom observation is an established tool for this purpose (Chism, 2007; Frantz et al., 2005; Jacobson, Wulff, Grooters, Edwards, \& Freisem, 2009; Jenson, 2002; Jones, Sagendorf, Morris, Stockburger, \& Patterson, 2009; Lewis, 2002; Millis, 2006; Wehlburg, 2005; Wilkerson \& Lewis, 2002) and "a powerful and effective faculty development strategy" (Wilkerson \& Lewis, 2002, p. 74). "Classroom observations powerfully document teaching activities, encourage reflection, foster constructive dialogues, and strengthen teaching," observes Millis (2005, p. 34).

Research demonstrates that teaching observations are an effective means of professional development (Hatzipanagos \& Lygo-Baker, 2006; Jacobson et al., 2009) that enable "ideas and techniques to be examined in more detail" (Hatzipanagos \& Lygo-Baker, 2006, p. 100). Hatzipanagos and Lygo-Baker found that the teaching observation process enhanced faculty members' understanding of learning and teaching strategies and deepened their knowledge. In their study of the long-term value and effects of teaching center observations, Jacobson et al. (2009) reported that faculty consultations led faculty to change their teaching practices, change their teaching perspective, and learn to work constructively with student feedback.

Educational developers have created general guides on conducting teaching observations (for example, Chism, 2007; Lewis, 2002; McKeachie, 2002; Millis, 2005, 2006; Wilkerson \& Lewis, 2002), devised a variety of forms (such as Chism, 2007), and offered tips on the process (for instance, Brinko, 1993; Jenson, 2002; Lewis, 2002), but the literature contains few examples of observational narratives that document what this powerful professional development process looks like. Chism (2007) includes a one-page example of a double-entry narrative log in her chapter on classroom observation, Wilkerson and Lewis (2002) offer suggestions on method, and Lewis (2002) gives an example of how to analyze participation in case study discussion. Jenson (2002) goes a step further in describing her method: "I drew a line down the notebook page and used one-half page for notes I thought the students would be taking 
and the other half for my observations" (p. 94). Although these examples are wonderful beginnings, none of the authors deconstructs the narrative to make explicit not only how we document what we do but also why we document what we do. This chapter seeks to fill that gap in the literature, demonstrating the value of a written record of teaching behaviors.

In the pages that follow, I review the generally agreed three-part process for conducting teaching observations as outlined by Chism (2007), McKeachie (2002), Millis (2006), and Wilkerson and Lewis (2002), which begins with a preobservation meeting, is followed by the observation itself, and concludes with a postobservation meeting. I describe the preparation necessary before the observation and the observation process in detail. Further, I identify an additional step in the process, the postobservation write up and analysis, in which the raw data or field notes from the observation are transformed into information for the faculty member. The transformation process has hitherto been a hidden and implicit part of the analysis, and the previous literature has failed to offer an interpretive frame that grounds our comments in the language of teaching and learning. Just as the art instructor I observed encouraged students to "use the vocabulary" in offering feedback on their peers' three-dimensional designs, we too need to couch our descriptions in our professional language and urge faculty to use our vocabulary to describe their work. This is appropriate use of an interpretive frame, and it gives faculty a new way of viewing their actions. To demonstrate the value of this approach, I give several examples of detailed observation narratives drawn from my experiences at several colleges and universities. Then I discuss communication and the postobservation meeting, and finally I draw some conclusions on the benefits of these narratives.

\section{Phase One: Preparing to Enter the Field (Preobservation)}

"Knowing what to look for is in fact a general principle applying to observations," notes McKeachie (2002, p. 324). During the preobservation meeting, educational developers ask questions of the faculty member, such as, "Do you have any areas of concern?" and "What questions would you like answered?" They should also request copies of relevant instructional materials such as the course syllabus, assignments, handouts, and other materials to support instruction such as PowerPoint slides. These materials are the blueprint of the course. Finally, this meeting is an opportunity to discuss the observation process in more detail, fleshing out when and where the observation will occur, and what it will look like. 
Reviewing the course materials prior to the observation gives me a better sense of where the class has been and where they are going. These materials also offer me a fuller sense of the educational context, the relationship of this course to others in the department, and its relationship to the major. In addition, I am able to give the instructor feedback on instructional design, whether the course goals and learning outcomes are being met, and whether the methods are appropriate to the goals and outcomes. As Jones et al. (2009) learned while developing a learningfocused classroom observation form, "effective course design is critical" (p. 209). Fink (2003) and Richlin (2006) also advise us to ask what we want students to know or be able to do as a result of our instruction and then design activities and assignments to achieve those outcomes. An added benefit of offering feedback on instructional materials, such as the syllabus or course assignments, is that the onus is not on the instructor per se, and thus he or she is less apt to take this feedback personally or as criticism. Assignments and syllabi can be easily modified. Taking care to frame comments as questions or suggestions can also help to reduce the appearance of evaluation. Once I have reviewed the course materials, I am ready to observe the class.

\section{Phase Two: Collecting the Data (the Observation)}

What do you document when you observe a class? I try to document everything using the narrative approach of a social scientific researcher. I try to record, as fully as possible, what the instructor says and does during the class, as well as student responses and behaviors. Thus, the teaching observation narrative resembles the field notes or diaries recorded by anthropologists.

Why use a written record, when one could create a digital or video record instead? As McKeachie (2002) observes, "Videotaping would seem on the face of it to be especially helpful. ... Nonetheless, videotaping may not be the best feedback" (p. 324). As he notes, subjects who are videotaped tend to focus so much on their own appearance and mannerism that they lose the larger point or purpose of the feedback. Videotaping can present a "more complete record of classroom events," Wilkerson and Lewis found; "[h]owever, it is more obtrusive, with both students and faculty reporting uneasiness and modification of their behavior to some extent" (2002, p. 74). In her analysis of the literature, Brinko (1993) refers to the process as "video self-confrontation" (p. 576) and remarks, "Video feedback is not for everyone. In many cases it can be a useful tool; in other cases it can be a threatening and stressful experience" (p. 582). 
I find that despite trying to observe the course from the students' point of view, I cannot fully remove my consultant's hat, although conducting multiple observations can counteract this tendency. Lewis (2002) describes how she takes on the typical student's role in the initial observation: "I take notes, may or may not read/do the assignment prior to class, try to make sense of the lecture, and write down whatever questions come to mind" (p. 67). In subsequent observations she shifts her role to educational developer.

Deciding what aspects of the classroom experience are worth attending to and recording is a skill (Lewis, 2002). The first part of the task is to describe what we see-specifically, the instructor behaviors we observe-with as much precision as possible, for example, differentiating among "Professor A. said ..." "Professor A asked ..." "Professor A explained ..." "Professor A showed ..." and "Professor A demonstrated." We should then do our best to write down what the instructor said, asked, explained, showed, or demonstrated, documenting both the action and the content. For instance:

Professor B connected student comments to one another, "That is like what Russ said," summarized, "It is a great focusing technique," and elaborated on student comments, as well as invited additional comments, asking: "Does anyone want to add to that?" and "Anybody else?" and "Who else?" She did not jump in to answer her own questions but rather waited for students to answer.

Likewise, we should record the student behaviors we observe. When the instructor poses a question, how do students react? Do they raise their hands, shout out an answer, consult their textbook or notes, or remain silent? What do they say, ask, note, comment on? Examples:

Professor C said, "Your role is to be a mentor." He asked, "What does it mean to be a mentor?" A student said, "A mentor is someone you look up to." A student offered, "Someone with wisdom and knowledge." Professor $C$ repeated student comments and wrote them on the board. Professor $\mathrm{C}$ called on students by name. "Jaycee?" Jaycee replied, "Someone who offers encouragement." Professor $\mathrm{C}$ asked, "What else?"

Professor D asked, "What is plagiarism? Who can tell me?" He waited for students to respond and repeated the question three times. When students still did not respond, he added, "It's on your handout." Students still did not respond. Finally, Professor D wrote the answer on the white board.

Students discussed bias and their reactions to the readings. A student commented, "This reminds me of something I saw on the Olympics-narrated by Oprah Winfrey, on Emmanuel." A student 
asked, "So how do you advocate for somebody and still have your own self-motivation? I see this all happen all the time. This is a very simple example. ..." A student gave an example of experiencing strong prejudice at Wal-Mart.

Another useful technique is to count specific behaviors: how many questions an instructor asked during a given class period, how many times students asked questions of the instructor, how many times students responded to the instructor, how many times the instructor called on students by name. For instance:

Throughout the class Professor $\mathrm{E}$ referred to students by name, using 20 names in the course of the class I observed. Professor $E$ was very polite and treated students with respect. When she needed to read from a student's handout, she asked, "May I read from yours? Thank you." She explicitly thanked students seven times for their contributions to discussion throughout the class. She gave explicit feedback in discussions, noting, "I heard you say ... " "And I noticed you also said. ..." She also gave students positive feedback on their responses in discussion, commenting, "Great." "Fantastic." "Interesting." "Lovely. I really like those." "Great." "Fantastic." "I really like that."

Professor $F$ asked over 76 questions in the class I observed, generating more than 66 student responses.

Professor $G$ asked 25 questions during the course of the lecture. Students responded to Professor G's questions, with some students calling out answers so the rest of the class could hear, and many students responding quietly in their seats.

Several students participated in the discussion (I counted 19 responses), with students responding to Dr. H's questions (7), students posing their own questions (2), students responding to other students' questions (2), students interjecting their own opinion (3), and students offering alternative theories and interpretations about the painting under discussion (5). Students referenced the text and readings in their responses.

\section{Phase Three: Interpreting and Analyzing the Data (the Write-up)}

After sitting in on a class and taking detailed notes, I compose a chronological narrative of everything that occurred. Depending on the nature and structure of the class, this narrative description is approximately three to seven (sometimes more) typed pages, single-spaced. This functions as what anthropologist Clifford Geertz called "thick description" 
(1973, p. 14). This detailed record of teaching behaviors and student responses can be one route to discovery. Many faculty have not seen themselves in action. The descriptions present snapshots or freeze frames of what they do and say in the classroom. Faculty can refer to them as they reflect on their teaching later.

Many faculty are grateful for this kind of detailed information. "This is so much more than I expected," is a typical comment. One faculty member added, "I will read through this a few more times to digest it all." Another wrote, "I can't thank you enough for the extensive work you have done for me in reviewing my teaching and the wonderful information to help me improve my ability to make a difference in the educational process of my students! I truly never expected so much effort on your part or the potential that I see in this document. I am amazed!"

These raw-data descriptions support the interpretation and analysis contained in the narrative and help keep the educational developer focused on the goal of "an observation that is developmental and not judgmental" (Hatzipanagos \& Lygo-Baker, 2006, p. 96). "Whatever observational system is chosen, the major criterion should be that the approach provides for the fullest description possible of classroom events with the least amount of observer inference and judgment required" (Wilkerson \& Lewis, 2002, p. 79). A variety of systems are available. What the best method is depends on the instructor, the situation, and the goals of the particular observation. Those with limited experience conducting observations can turn to Chism's Peer Review of Teaching: A Sourcebook for options and advice (2007).

Teaching observations should help faculty evaluate the effectiveness of their teaching behaviors (Wilkerson \& Lewis, 2002). Judgment should be kept limited, but offering an interpretive frame and grounding our comments in the language of teaching and learning is important, because it gives faculty a new way of looking at their actions. As Fink (2003) observed, "A consultant can be an important resource by providing informed, personalized feedback as well as general information about teaching and learning" (p. 55).

The next examples illustrate how the addition of interpretive comments strengthens the feedback, starting with this one:

Professor I began the class by explaining that she had altered the color scheme on her PowerPoint slides per the request of a visually impaired student. Instead of using a light background and dark letters (her usual approach), she used a dark background and light letters to help the student see better. 
Adding the interpretation, "Professor I displayed concern for student learning," helps faculty members recognize this behavior as studentcentered. Here is a second example:

Professor J distributed blank note cards to the class and asked them to write down their responses to the questions: "What are you excited about? What do you have anxiety about? What are you nervous about?" He instructed students to write anonymously, "No names." He collected the cards and shuffled them, then asked, "Who wants to read one? What's out there?"

Adding the interpretive comment, "This classroom assessment technique [CAT] was useful in making students' anxieties visible, in an interactive manner" helps instructors see their teaching behaviors in a new way. Finally, consider this third example:

Each student took a turn reading a card, so that all voices were heard. Professor K, said, "All feedback is valid." He summarized comments. He asked students, "What themes did you hear?" Common themes included being nervous about being interviewed, videotaped, and recorded. Professor $\mathrm{K}$ asked, "How does knowing about these concerns help you?" $\mathrm{A}$ student commented, "It is weird to watch yourself on tape." Professor $\mathrm{K}$ agreed, "It is weird," and displayed humor. A student commented, "When you watch yourself, you focus on 'ums,' 'likes,' etc."

Following this description with an interpretation, "Professor $\mathrm{K}$ demonstrated concern for student learning by explicitly seeking student feedback on their affective learning and addressing those concerns in class," explains the teaching behaviors and their impact on student learning and classroom climate.

An interpretive comment can also make the purpose of the teaching behavior more explicit, as in this example:

When a student asked a question about the F.M. device, Professor $\mathrm{L}$ responded: "Let me summarize what you said and rephrase it." This allowed Professor $\mathrm{L}$ to repeat the content information in another way for the benefit of the whole class.

The description and the interpretation may even occur simultaneously:

Professor $\mathrm{M}$ integrated student comments as he guided the discussion. For example, when discussing support for new interpreters, he remarked, "Another issue both you and Michelle touched on is what do you do when you have limited apprenticeship and mentoring?" 
Framing the observation in the vocabulary of teaching and learning can give faculty a new, more professional understanding of their teaching. They may learn that one of their instructional activities has a name in the college-teaching literature: as in the next example, a CAT (Angelo \& Cross, 1993):

Professor $\mathrm{N}$ used two classroom assessment techniques. During the class he used several scenarios to check student understanding. For instance, he asked: "What if you are a service provider and __ happens? What do you do?" These questions promoted higher-order thinking as students had to apply the information learned to situations that were drawn from real-life experience. Professor $\mathrm{N}$ ended the class with a quiz that also checked students' understanding. The questions were on the PowerPoint slide and could be seen by all, and served as a summation of the lecture material.

In addition, faculty may not be aware of the multiple uses of their teaching behaviors. Questions, for example, can be used in a variety of ways.

Professor $\mathrm{O}$ used questions effectively to maintain student interest, to keep students involved and engaged with the material, and to propel the lecture forward. In the class I observed, Professor $\mathrm{O}$ asked 25 questions during the course of the lecture. His questions connected the course content to theory and readings when he asked "What is the theory called?" or "Is that why it's only a theory?" He asked students about the chemical reactions that occur to produce movement: "What does ATP do here?" and "What do we need for muscle tension to develop?" and "What has to happen to the nerve stimulus?" He used questions to elicit higher-order thinking on Bloom's taxonomy, asking "Why?" "What is the difference between this graph and the previous graph?" "What about the overall tension?" He used questions to get students to make predictions: "What's going to happen to the myosin head? What's it going to do? Have we moved at all?" "Now what will happen? What's going to happen next?" and "What is the next phase? What is happening at this time?" He used questions to get students to reflect on the course content: "Is this the way you move?" Professor $O$ also used questions as transitions: "Now we know how it works. What happens when it doesn't work?" Professor $O$ used questions to connect with students' experiences. "Who here has never had the hiccups?" and "When the medical examiner on TV examines a corpse, what are they checking for? What is rigor mortis? What's going to happen to the body?" and "What muscle do you not want affected by 
bacterial tetanus?" He also incorporated students' questions into his own questions: "Now it comes back to what was brought up by Katelyn-are twitches useful?"

In another class, I noted:

Professor Q's questions were sequenced and built on one another, sometimes following a pattern such as "How did we ... ?" "Why did we . . ?" "What did we learn?" "How else can we do this?" "What might be the problem?" "Can anyone see a difficulty?" "Could we do this better?" "What does the research tell us?"

For another faculty member, it was helpful to furnish a typology of the questions she asked to help her understand how they influenced learning. Probing questions:

At the next piece, a student commented, "It is an interesting piece." Professor R replied, “Because?” The student elaborated, “Because of the negative space." Professor $\mathrm{R}$ asked, "What has happened here because of the negarive space? Where is the dominant?" Professor $R$ used questions to focus students' attention and get them to think critically about each piece.

Elaborating questions:

A student commented, "My eye gets stuck at the top [of the piece]." Professor R probed more deeply, asking, "What would you suggest?" urging the student to elaborate and make the comment more specific. At the next piece Professor $R$ asked, "What do you have to say about this?" A student replied, "I like the corner." Professor R replied, "Because?" asking the student to elaborate and be more specific. The student explained that the piece "moved to flat surface to show the angles." Professor $R$ explained, "It creates a focal point. The negative space is activated, really lovely differential."

Narrative teaching observations also allow educational developers to focus on teachable moments. For example, in an art class:

The instructor asked, "Was that supposed to be a piercing?" The artist replied, "I changed my mind." The instructor commented, "That's smart thinking." She probed, "Why would you think it might not work? What's happening here that isn't happening in anyone else's work? What form?"

I prefer to use a naturalistic process and let the data guide me. When I go back over the field notes or raw data, I often use different colored 
pens and highlighters to help me identify topics, categories, or themes. As I review the chronological record, I consider how the class is organized, where the instructor spent the most time, how students responded, what the learning outcomes were and the degree to which they were met, what stood out to me as an observer, what worked well, and whether the instructor encountered any difficulties or challenges. These general questions guide my interpretation and analysis.

When the purpose of the observation is to improve poor performance, I find it helpful to begin with a description, such as, "I noted that the directions for the activities were given orally and at times students were unclear about the directions." I then ask questions or make corrective suggestions. In this case, I asked: "Are there other ways to give directions or ways to help visually repeat them so students understand them more readily? Would it be helpful to have the directions written on a handout you distribute when you put students in groups or display them on in your PowerPoint slides or on the document camera at the beginning of the activity so that everyone can see?"

In another course, where students showed confusion over similarly titled assignments, I suggest a quick way to differentiate the tasks: copying them on colored paper. The instructor could then remind students, "The blue one is due today, and the yellow one is due next week." The next term the instructor could retitle them.

Another way to begin a narrative targeted to improve teaching is by acknowledging the difficulty of the situation. For example, late afternoon and early evening classes can be challenging for students and faculty because they are tired. Commenting on a difficulty we all share removes some of the onus from the instructor and communicates empathy. Offering examples of how other faculty have dealt with a problem can also be helpful. For instance, I shared that low energy was a problem in another late afternoon class I recently observed. The faculty member noticed that students were fading and not paying attention.

Instead of scolding them, she explained, "For the next thirty minutes we will be offering feedback to one another on the projects. This is a really important part of the course, and it is really important for everyone to give this task their full attention and energy. We need to give everyone's work the respect it deserves. I notice that several people are tired and not very focused. Let's take a two-minute break. Get up, walk around, walk up and down the hall, get a drink, and come back so that we can all give our best effort to our peers." 
In addition to asking questions and making suggestions, it is helpful to include details to support one's conclusions, as in this example:

Are there ways to adjust the pacing of this class so that things move along more quickly? For instance, students worked in groups creating graphic organizers for some 20 to 30 minutes while you graded their journal responses. Students appeared to have completed the task in 10 to 15 minutes. How could this extra time be best used?

To supply additional resources for improvement, I often append a Part B to my observations that includes suggestions, models, and references tailored to solving the teaching problems the faculty member may have. As Jones et al. (2009, p. 209) advise, "Teaching cannot be boiled down to a recipe."

\section{Phase Four: Meeting with the Instructor (the Postobservation Meeting)}

The final step in the process is the face-to-face postobservation meeting with the faculty member. Complementing the written narrative, it brings together two professionals to engage in discussion and a process of problem solving: identifying a problem, identifying possible reasons for it, and exploring strategies to address it (DiPietro, 2008). The teaching observation can be an effective means of professional development as long as we remember its true purpose, to "build a relationship, not a case" (Jenson, 2002, p. 97). Our relationships with faculty rest on trust (Hatzipanagos \& Lygo-Baker, 2006), and as professionals we have ethical obligations to treat faculty fairly and respect confidentiality. For a detailed explanation of these responsibilities, please refer to the Ethical Guidelines for Faculty Developers forwarded by the POD Network, printed near the front of this volume.

\section{Conclusion}

The detailed examples in this chapter illustrate the many benefits of narrative teaching observations. First, because narratives furnish detailed snapshots of given moments in time, they document effective (and less effective) teaching behaviors. Second, because they are written, they afford a permanent record that can be referred back to later. Third, because they supply an interpretive frame that videotapes and digital recordings cannot, they help faculty recognize and understand their own behavior. Fourth, because they can accommodate suggestions, models, 
and references, they help faculty members solve problems they may be encountering. Fifth, the narrative is flexible and useful in a variety of contexts and situations. As each class is a unique event: "Teaching observations involve complex social situations with large numbers of variables that cannot be controlled" (Hatzipanagos \& Lygo-Baker, 2006, p. 99).

One final benefit these narratives offer is the opportunity for us to describe teaching behaviors using our professional vocabulary. Our agreed-on terminology reflects our in-depth understanding of these behaviors and allows us to integrate our knowledge of their pedagogical impacts. Therefore, it serves not to obfuscate but to illuminate the teaching process and make it more transparent (Hatzipanagos \& Lygo-Baker, 2006). Given its high utility, our vocabulary merits broader dissemination across the academy. Our using it helps the narrative teaching observation make the how and the why of our professional practice more explicit and our contribution as faculty developers more evident.

\section{REFERENCES}

Angelo, T. A., \& Cross, K. P. (1993). Classroom assessment techniques: $A$ handbook for college teachers (2nd ed.). San Francisco: Jossey-Bass.

Brinko, K. T. (1993). The practice of giving feedback to improve teaching: What is effective? Journal of Higher Education, 64(5), 574-593.

Chism, N.V.N. (2007). Peer review of teaching: A sourcebook (2nd ed.). Bolton, MA: Anker.

DiPietro, M. (2008, October). An online tool for teaching consultations. Paper presented at the 33rd annual meeting of the Professional and Organizational Development Network in Higher Education, Reno, NV.

Fink, L. D. (2003). Creating significant learning experiences: An integrated approach to designing college courses. San Francisco: Jossey-Bass.

Frantz, A. C., Beebe, S. A., Horvath, V. S., Canales, J., \& Swee, D. E. (2005). The roles of teaching and learning centers. In S. Chadwick-Blossey \& D. R. Robertson (Eds.), To improve the academy: Vol. 23. Resources for faculty, instructional, and organizational development (pp. 72-90). Bolton, MA: Anker.

Geertz, C. (1973). Thick description: Toward an interpretive theory of culture. New York: Basic Books.

Hatzipanagos, S., \& Lygo-Baker, S. (2006). Teacher observations: A meeting of minds? International Journal of Teaching and Learning in Higher Education, 17(2), 97-105.

Jacobson, W., Wulff, D. W., Grooters, S., Edwards, P. M., \& Freisem, K. (2009). Reported long-term value and effects of teaching center consultations. 
In L. B. Nilson \& J. E. Miller (Eds.), To improve the academy: Vol. 27. Resources for faculty, instructional, and organizational development (pp. 223-246). San Francisco: Jossey-Bass.

Jenson, J. D. (2002). If I knew then what I know now: A first-year faculty consultant's top ten list. In K. H. Gillespie, L. R. Hilsen, \& E. C. Wadsworth (Eds.), A guide to faculty development: Practical advice, examples, and resources (pp. 92-98). Bolton, MA: Anker.

Jones, S. K., Sagendorf, K. S., Morris, D. B, Stockburger, D., \& Patterson, E. T. (2009). Lessons learned from developing a learning-focused classroom observation form. In L. B. Nilson \& J. E. Miller (Eds.), To improve the academy: Vol. 27. Resources for faculty, instructional, and organizational development (pp. 199-222). San Francisco: Jossey-Bass.

Lewis, K. G. (2002). The process of individual consultation. In K. H. Gillespie, L. R. Hilsen, \& E. C. Wadsworth (Eds.), A guide to faculty development: Practical advice, examples, and resources (pp. 59-73). Bolton, MA: Anker. McKeachie, W. J. (2002). McKeachie's teaching tips: Strategies, research, and theory for college and university teachers (11th ed.). Boston: Houghton Mifflin. Millis, B. J. (2005, October). Conducting effective classroom observations. Paper presented at the 30th annual meeting of the Professional and Organizational Development Network in Higher Education, Milwaukee, WI.

Millis, B. J. (2006). Peer observations as a catalyst for faculty development. In P. Seldin \& Associates, Evaluating faculty performance: A practical guide to assessing teaching, research, and service (pp. 82-95). Bolton, MA: Anker.

Palmer, P. J. (1998). The courage to teach: Exploring the inner landscape of a teacher's life. San Francisco: Jossey-Bass.

Professional and Organizational Development Network in Higher Education. (2007). Ethical guidelines for educational developers. Retrieved March 2, 2009 , from www.podnetwork.org/faculty_development/ethicalguidelines.htm

Richlin, L. (2006). Blueprint for learning: Constructing college courses to facilitate, assess, and document learning. Sterling, VA: Stylus.

Tompkins, J. (1993). Postcards from the edge. Journal of Advanced Composition, 13(2), 449-457.

Wehlburg, C. M. (2005). Using data to enhance college teaching: Course and departmental assessment results as a faculty development tool. In S. Chadwick-Blossey \& D. R. Robertson (Eds.), To improve the academy: Vol. 23. Resources for faculty, instructional, and organizational development (pp. 165-172). Bolton, MA: Anker.

Wilkerson, L., \& Lewis, K. G. (2002). Classroom observation: The observer as collaborator. In K. H. Gillespie, L. R. Hilsen, \& E. C. Wadsworth (Eds.), A guide to faculty development: Practical advice, examples, and resources (pp. 74-81). Bolton, MA: Anker. 